\title{
Olive tree in vitro establishment under different culture media and explant collection periods
}

\author{
Roseane Maidana Moreira ${ }^{1, *}$, Márcia Wulff Schuch ${ }^{1}$, Zeni Fonseca Pinto Tomaz ${ }^{1}$, Amanda da Fonseca \\ Borges $^{1}$ and Cari Rejane Fiss Timm
}

${ }^{1}$ Universidade Federal de Pelotas, Programa de Pós-Graduação em Agronomia, Fruticultura de Clima Temperado, Departamento de Fitotecnia, Caixa Postal 354, CEP 96010-900, Pelotas, Rio Grande do Sul, Brazil. *Corresponding author, E-mail: roseane_moreira@ @otmail.com

\begin{abstract}
In the species Olea europaea L. the tissue culture techniques have not been sufficiently studied by the lack of efficient establishment of protocols for various cultivars. The objective of this work was to evaluate the effect of different culture media and sampling times of explants on in vitro establishment of six cultivars of olive (Ascolano 315, Leccino, Maria da Fé, Coratina, Arbequina and Frantoio). The work was divided into two experiments conducted in the Fruit Tree Propagation Laboratory, Crop Science Department, Faculty of Agronomy Eliseu Maciel, Federal University of Pelotas, Brazil. Stock plants of the olive cultivars maintained in semi- hydroponic system were used. In the first experiment, nodal segments were used to establish in vitro culture medium MO and WPM, consisting of salts and vitamins. In the second experiment four seasons to obtain the explants were evaluate (autumn, winter, spring and summer). The WPM medium promoted greater establishment of olive explants. There is a higher phenolic oxidation in olive explants collected in winter. Spring is indicated for collecting explants, therefore favors the in vitro cultivar Maria da Fé, while Ascolano 315 and Arbequina cultivars have a higher rate of in vitro establishment by collecting explants over the year.
\end{abstract}

Key words: Olea europaea, micropropagation, phenolic oxidation, seasons.

\section{INTRODUCTION}

The olive tree (Olea europaea L.) belongs to the Oleaceae family and has great economic importance to Mediterranean countries. According to Teramoto et al. (2013), Brazil is the world's second olives importer and, in the last decade, Brazilian table olives imports more than doubled. However, commercial cultivation in Brazil is still a recent and expanding agricultural activity (Oliveira et al., 2009) which aims at reducing by $30 \%$ the importation of olive oils. According to Jorge (2013), the most appropriate regions for olive trees production in the gaucho soil are those located in the Campanha do Rio Grande do Sul region, next to Uruguay, although it is likely that, in this state, production has been developed in the Bagé, Dom Pedrito and Uruguaiana region.

The increasing olive tree's growing trend in the country has generated a demand for seedlings to supply the market, requiring research and new technical information on the production of these seedlings (Conab 2009). According to Coutinho et al. (2015), vegetative propagation is the most viable technique for the development of olive tree seedlings, thus maintaining the genetic characteristics of mother plants, uniformity, reduced size and production precocity. Therefore, studies on the commercial propagation of this species has become essential, including micropropagation. However, to develop micropropagation protocols, it is necessary first to establish it in vitro.

Tissue culture applications remain unexplored in olive trees due to the lack of efficient establishment protocols for most cultivars. One of the problems faced by this species is related mainly to in vitro oxidation due to phenolic compounds release. These compounds, according to Taiz and Zeiger (2013) have a variety of functions in plants, some act as defense compounds against pathogens and herbivores, and others as attraction to pollinators.

Explants in vitro growth is also related to culture medium formulation and may show response variations for different cultivars tissues. Therefore, many media are being tested such as MO salts and vitamins (Rugini 1984), MS salt and vitamins (Murashige and Skoog 1962) and WPM salts and vitamins, the latter developed for woody plants in general (Lloyd and Mccown 1980). Rugini (1984) proposed the MO medium for the regeneration of some olive tree cultivars.

Taking into account that the availability of healthy olive tree seedlings is a determining factor for the development of commercial orchards, the production of micropropagated seedlings may be an alternative for the production of certified seedlings. With the objective to develop protocols for the in vitro establishment of olive trees, the objective of the present work was to evaluate the effect of explants collection periods in culture media (WPM and MO), on the establishment of olive tree cultivars.

\section{MATERIALS AND METHODS}

Experiments were conducted at the Department of Plant Science Fruit Plants Propagation Laboratory from Faculdade de Agronomia Eliseu Maciel, Universidade federal de Pelotas, RS. For the olive tree in vitro 
establishment, four-year-old mother plants from the Germoplasm Active Bank of UFPel, were kept in 90L vases under a hydroponic system, irrigated with nutritive solution and formulated by Schuch and Peil (2012), according to the needs of the culture. To reduce in vitro contamination, mother plants were pulverized every two days, with the minimum of three applications, with Kasumin ${ }^{\circledR}$ (bactericide) and Cercobin ${ }^{\circledR}$ (fungicide), at the dosages of 3 ml.L $\mathrm{L}^{-1}$ and 0.7 g.L $\mathrm{L}^{-1}$, respectively.

New olive tree shoots, with approximately $2 \mathrm{~cm}$ and two buds, had their leaves removed at collection. First, explants were disinfected with alcohol at $70 \%$, under agitation, for 1 minute. Then they were immersed in sodium hypochlorite at the concentration of $2.5 \%$ of active chlorine, adding two drops of Tween 20 , for 15 minutes, in contact with the explants, under agitation. Next, the disinfected material was washed three times using autoclaved distilled water and sterilized in a laminar flow chamber, for posterior explants isolation.

In the first experiment, the in vitro establishment of olive tree cultivars was assessed under different culture media. The experiment included a $6 \times 2$ (cultivars and culture media) factorial design. Treatment variation sources were cultivars Ascolano 315, Leccino, Maria da Fé, Coratina, Arbequina e Frantoio and the culture media: WPM and MO.

The experimental design was entirely randomized, with 12 treatments and four replications, using 12 tubes per replication, with one explant per test tube. Nodal segments of approximately $2 \mathrm{~cm}$ were used for the in vitro establishment. Tested culture medium included MO salt and vitamins (Rugini 1984) and WPM salts and vitamins (Lloyd and Mccown 1980), plus $2 \mathrm{mg} . \mathrm{L}^{-1}$ BAP with $100 \mathrm{mg} . \mathrm{L}^{-1}$ of myoinositol, $30 \mathrm{~g} . \mathrm{L}^{-1}$ of sucrose, with the pH adjusted to 6.0 before the inclusion of agar at the concentration of 6 g.L. ${ }^{-1}$ and, later, autoclaved at $121^{\circ} \mathrm{C}$ and 1.5 atm for 20 minutes. Test tubes $(150 \times 20 \mathrm{~mm})$ contained $7 \mathrm{ml}$ of culture medium.

After inoculation, explants were kept in the dark for seven days to reduce phenolic oxidation. Next, they were transferred to a growth room with photoperiod of 16 hours of light and 8 hours of darkness, with radiation of $27 \mu \mathrm{mol} . \mathrm{m}^{-2} \mathrm{~s}^{-1}$ and temperature of $25 \pm 2^{\circ} \mathrm{C}$. The experiment evaluated collection periods at the in vitro establishment if olive tree cultivars.

The experiment adopted a 6x4 factorial design (cultivars and collection periods). The following cultivars were the treatments variation sources: Ascolano 315, Leccino, Maria da Fé, Coratina, Arbequina and Frantoio and the following collection periods: (Fall, Winter, Spring of 2012 and Summer of 2013). Experimental design was entirely randomized, with 24 treatments and 4 replications, using 12 tubes, with an explant per replication. The culture medium for the in vitro establishment of nodal segments included WPM salts and vitamins (Lloyd and Mccown 1980) plus 2 mg.L ${ }^{-1}$ BAP.

In both experiments, evaluations took place at 7, 14, 21 and 28 days of cultivation to assess bacterial contamination, fungal contamination and oxidized explants percentages. Flasks that showed contamination and/or oxidation were eliminated after registration. At 45 days of cultivation, the material was evaluated in regards to survival percentage, indicated by the green color of the nodal segment, and establishment percentage, determined by the development of leaf primordia and the presence of shoots (Figure 1).

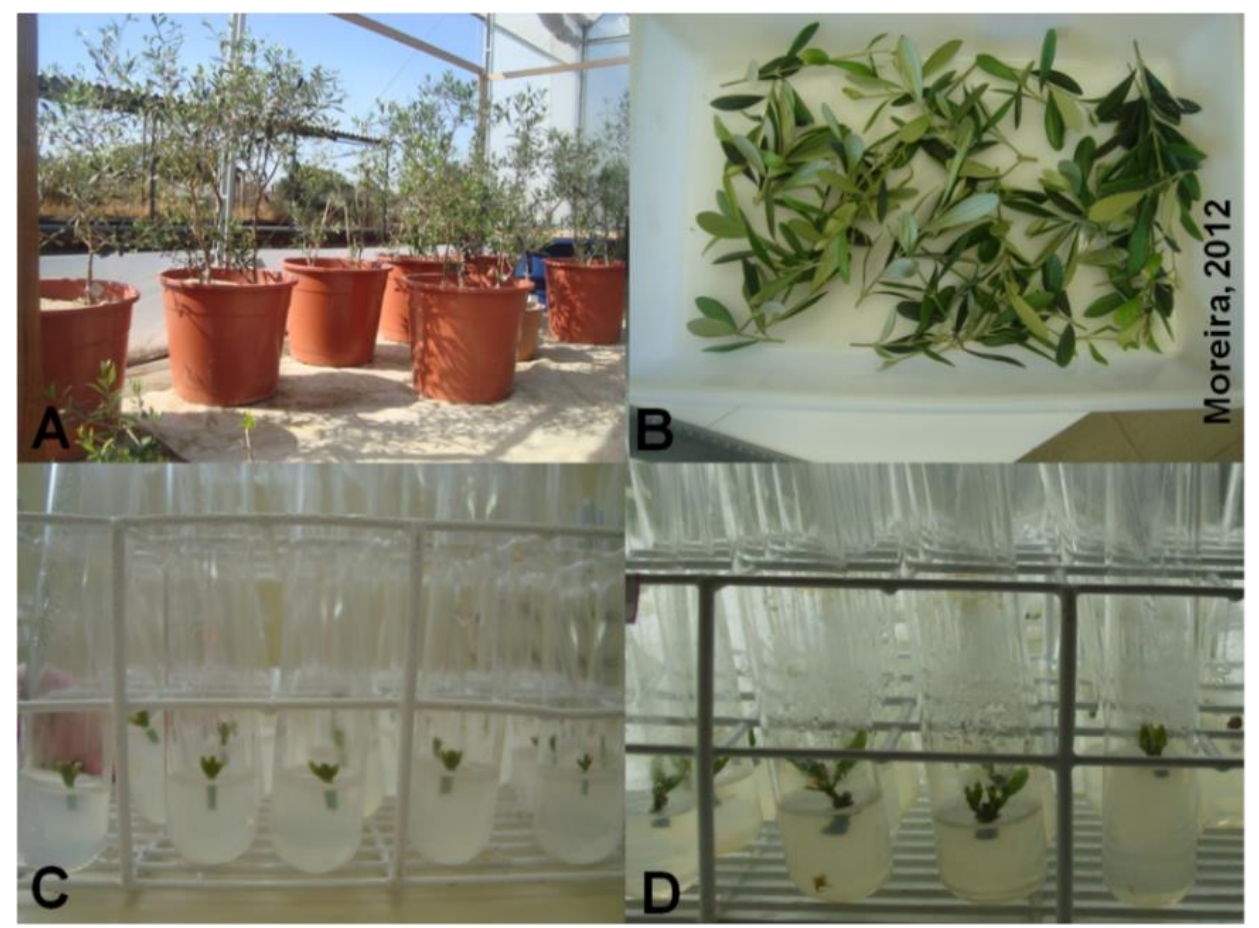

Figure 1. Stock plants of olive (A), material collection (B), inoculated explants in vitro (C), and explants established in a WPM culture mean at 45 days of cultivation, 2012 (D). Pelotas, RS, Brazil. 2014. 
Data were submitted to an analysis of variance by the F test and means compared by the Tukey test at $5 \%$ of probability of variables analyzed sequentially (at different cultivation days). Regressions among established variables were significant whenever $\mathrm{p} \leq 5 \%$ by the WinStat statistical program (Machado and Conceição 2010). Data in percentages were transformed in the arc sine of $\sqrt{\frac{X}{100}}$, were $\mathrm{x}$ is the percentage.

\section{RESULTS AND DISCUSSION}

Results showed an interaction between cultivars and the culture media in the first experiment. Higher oxidation percentages were found for the MO culture medium for most cultivars, probably due to its highest salt concentrations. Cultivar Frantoio showed no significant difference for this factor (Table 1). These data differ for those presented by Donini et al. (2008b) on olive tree in vitro establishment, in which the authors obtained a low oxidation percentage for the MS, MO and WPM media. However, this same work shows high rates of fungal contamination for the three tested media.

According to Table 1, cultivar Maria da Fé showed the highest fungal contamination for the WPM medium. By studying disinfestation and culture medium in the in vitro establishment of Liquidambar styraciflua nodal segments, Brondani et al. (2010) obtained reduced fungal contamination values (14\%) in a WPM medium. They immersed explants in $\mathrm{NaOCl}$ at $5 \%(\mathrm{v} / \mathrm{v})$ (approximately $2.5 \%$ of active chlorine), for 10 minutes and in a benomyl-based solution for 40 minutes, at $1 \%(\mathrm{p} / \mathrm{v})$, as an active ingredient. In an in vitro establishment experiment with cultivar Koroneiki, Donini et al. (2008a) obtained 26.3\% of contaminated explants in a WPM culture medium.

Results showed low bacterial contamination and no significant difference between cultivars Leccino, Coratina and Frantoio for the tested media (Table 1). Dias et al. (2013), working on the in vitro establishment of pomegranate tree (Punica granatum L.), also found low bacterial contamination (2.35\% of explants) at 30 days of in vitro cultivation. In the present study, cultivar Ascolano 315 showed the highest bacterial contamination percentage for the WPM medium (Table 1). However, this percentage is lower than that found by Palu et al. (2011), who obtained $39.14 \%$ of contamination by bacteria in fig tree apical buds, using cephalothin sodium antibiotics $150 \mathrm{mg} . \mathrm{L}^{-1}$ in a MS culture medium.

Table 1. Percentage of oxidation, fungal contamination and bacterial contamination in olive tree explants established in vitro, in MO and WPM culture media, 2012. Pelotas, RS, Brazil. 2014.

\begin{tabular}{|c|c|c|}
\hline \multirow{3}{*}{ Cultivars } & \multicolumn{2}{|c|}{ Oxidation (\%) } \\
\hline & \multicolumn{2}{|c|}{ Media } \\
\hline & MO & WPM \\
\hline Ascolano 315 & $43.22 \mathrm{aC}^{1}$ & $14.06 \mathrm{bD}$ \\
\hline Leccino & $57.29 \mathrm{aB}$ & $29.68 \mathrm{bBC}$ \\
\hline Maria da Fé & $55.72 \mathrm{aB}$ & $25.52 \mathrm{bCD}$ \\
\hline Coratina & $76.04 \mathrm{aA}$ & $39.58 \mathrm{bB}$ \\
\hline Arbequina & $55.72 \mathrm{aB}$ & $22.39 \mathrm{bCD}$ \\
\hline \multirow[t]{2}{*}{ Frantoio } & $71.35 \mathrm{aA}$ & $66.66 \mathrm{aA}$ \\
\hline & \multicolumn{2}{|c|}{ Fungal contamination $(\%)$} \\
\hline Ascolano 315 & $27.60 \mathrm{aA}$ & $24.47 \mathrm{aB}$ \\
\hline Leccino & $25.00 \mathrm{aA}$ & $24.47 \mathrm{aB}$ \\
\hline Maria da Fé & $18.75 \mathrm{bAB}$ & $48.95 \mathrm{aA}$ \\
\hline Coratina & $10.41 \mathrm{aBC}$ & $10.93 \mathrm{aC}$ \\
\hline Arbequina & $12.49 \mathrm{aBC}$ & $7.29 \mathrm{aC}$ \\
\hline \multirow[t]{2}{*}{ Frantoio } & $12.49 \mathrm{aC}$ & $7.29 \mathrm{aC}$ \\
\hline & \multicolumn{2}{|c|}{ Bacterial contamination $(\%)$} \\
\hline Ascolano 315 & $4.16 \mathrm{bA}$ & $13.54 \mathrm{aA}$ \\
\hline Leccino & $2.60 \mathrm{aA}$ & $1.56 \mathrm{aCD}$ \\
\hline Maria da Fé & $0.00 \mathrm{bA}$ & $3.64 \mathrm{aCD}$ \\
\hline Coratina & $4.16 \mathrm{aA}$ & $5.20 \mathrm{aBC}$ \\
\hline Arbequina & $1.04 \mathrm{bA}$ & $8.33 \mathrm{aB}$ \\
\hline Frantoio & $2.08 \mathrm{aA}$ & $0.00 \mathrm{aD}$ \\
\hline
\end{tabular}

${ }^{1}$ Uppercase letters compare columns and lower case compare lines. 
At 45 days of in vitro cultivation, there was a significant difference between the tested media, making the highest percentage of explants established in a WPM culture mean more evident, according to Table 2 .

Table 2. Percentage of in vitro established and survivor olive tree explants in MO and WPM culture media, at 45 days of cultivation, 2012 Pelotas, RS, Brazil. 2014.

\begin{tabular}{|c|c|c|}
\hline \multirow{3}{*}{ Cultivars } & \multicolumn{2}{|c|}{ Establishment (\%) } \\
\hline & \multicolumn{2}{|c|}{ Media } \\
\hline & MO & WPM \\
\hline Ascolano 315 & $2.08 \mathrm{bA}^{1}$ & $31.24 \mathrm{aAB}$ \\
\hline Leccino & $0.00 \mathrm{bA}$ & $27.08 \mathrm{aAB}$ \\
\hline Maria da Fé & $8.33 \mathrm{aA}$ & $16.67 \mathrm{aBC}$ \\
\hline Coratina & $0.00 \mathrm{bA}$ & $14.58 \mathrm{aBC}$ \\
\hline Arbequina & $0.00 \mathrm{bA}$ & $37.50 \mathrm{aA}$ \\
\hline \multirow[t]{2}{*}{ Frantoio } & $0.00 \mathrm{aA}$ & $8.33 \mathrm{aC}$ \\
\hline & \multicolumn{2}{|c|}{ Survivors (\%) } \\
\hline Ascolano 315 & $0.00 \mathrm{a}$ & $0.00 \mathrm{aB}$ \\
\hline Leccino & $0.00 \mathrm{~b}$ & $6.25 \mathrm{aAB}$ \\
\hline Maria da Fé & $0.00 \mathrm{a}$ & $0.00 \mathrm{aB}$ \\
\hline Coratina & $0.00 \mathrm{~b}$ & $12.5 \mathrm{aA}$ \\
\hline Arbequina & $0.00 \mathrm{a}$ & $4.16 \mathrm{aB}$ \\
\hline Frantoio & $0.00 \mathrm{a}$ & $4.16 \mathrm{aB}$ \\
\hline
\end{tabular}

${ }^{1}$ Uppercase letters compare columns and lowercase compare lines.

Cultivars Arbequina and Ascolano 315 showed the highest means in the WPM medium. These data agree with those found by Donini et al. (2008b), who observed better shoot means for the establishment of the 'Arbequina' olive tree in a WPM medium.

As for the survival evaluated at 45 days of cultivation, there was no surviving explant in the MO culture medium (Table 2), which is related to the high rate of oxidized explants. WPM showed $12.5 \%$ of surviving explants for cultivar Coratina. This result differs from that found by Costa et al. (2007), who obtained $37.50 \%$ of rosemary pepper (Lippia sidoides Cham.) surviving explants in the WPM culture medium. However, Bassan et al. (2006) verified a highest cassia fistula (Peltophorum dubium (Spreng.) survival and establishment rate in a MS medium than those maintained in WPM.

The second experiment showed significant difference for the phenolic oxidation variable, in the Fall, for cultivars Frantoio e Leccino, which showed 79 and $39 \%$ of oxidized explants, respectively,at 28 days of in vitro cultivation (Figure 2A). Donini et al. (2008a), studying the in vitro establishment of olive tree cultivars under different light quality, verified that cultivar Frantoio showed the highest phenolic oxidation rate at 21 and 2 days of in vitro cultivation.

Cultivar Arbequina showed the highest oxidation percentage at 21 days of in vitro cultivation in winter in relation to the other tested cultivars (Figure 2B). Dias et al. (2013) obtained $82.37 \%$ of oxidized explants for the in vitro establishment of pomegranate trees.

In spring, cultivars Maria da Fé and Frantoio showed no significant difference in regards to phenolic oxidation and cultivar Leccino showed the lowest percentage (41\%) in this period (Figure 2C). Scherer-Salvaro et al. (2009) observed a high oxidation percentage in java citronella explants (Cymbopogon winterianus Jowitt) collected in winter and spring and established in vitro.

Figure 2D shows the increasing linear response from explants oxidation in function of an increase in number of cultivation days in the five cultivars tested in summer, with no significance only for the Maria da Fé cultivar. Cultivars Leccino and Coratina showed the highest oxidation percentage at 28 days, which could be related to internal and external factors that control the production of phenolic compounds such as hormones and light

In regards to bacterial contamination, there was an increase throughout the in vitro establishment for explants from the Coratina cultivar collected in the Fall (Figure 3A) and Maria da Fé cultivar collected in the Winter (Figure 3B), corresponding to 10 and $20 \%$ of the contaminated explants at 28 days of cultivation. During the in vitro establishment of the blueberry tree cultivars Bluecrop, Misty and Duke, Pelizza et al. (2013) obtained, respectively, $25.02 \%, 20.03 \%$ and $27.29 \%$ of bacterial contamination.

The analysis of variance showed no significant effect for fungal contamination in different olive tree cultivars tested for the four seasons of the year. These results differ from those found by Donini et al. (2008a), who obtained $26.3 \%$ of contamination in the in vitro establishment of the Koroneiki olive tree cultivar. 
FALL

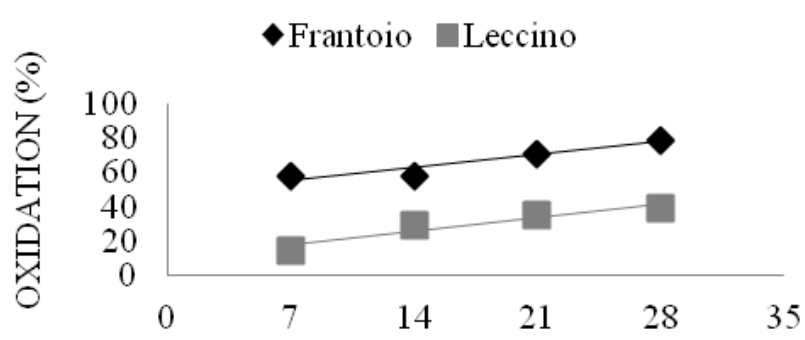

IN VITRO CULTIVATION DAYS

Frantoio: $y=7.50 x+55.42 R^{2}=0,9$

Leccino: $y=8.12 x+17.50 R^{2}=0,92$.

A

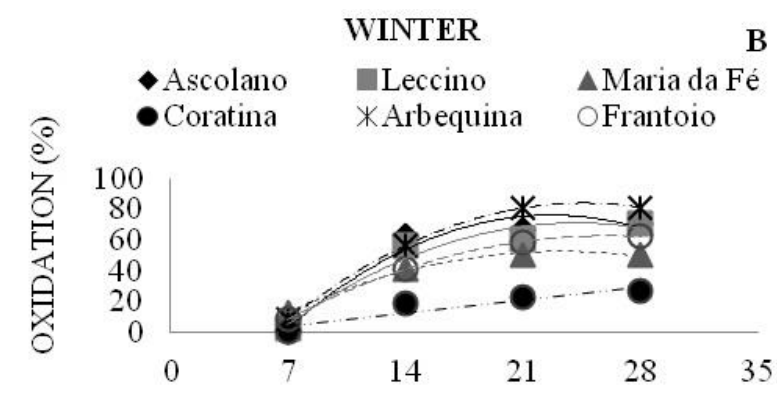

IN VITRO CULTIVATION DAYS

Ascolano: $\mathrm{y}=-14.58 \mathrm{x} 2+65.42 \mathrm{x}+2.92 \mathrm{R}^{2}=0.95$

Leccino: $y=-10.94 \times 2+53.85 x+4.90 R^{2}=0.94$

Maria da Fé: $y=-7.30 x 2+33.95 x+13.12 R^{2}=0.99$

Coratina: $\mathrm{y}=8.54 \mathrm{x}+4.38 \mathrm{R}^{2}=0.85$

Arbequina: $y=-11.98 \times 2+60.31 x+8.22 R^{2}=0.99$

Frantoio: $y=-7.39 x 2+39.80 x+8.54 R^{2}=0.99$
SPRING

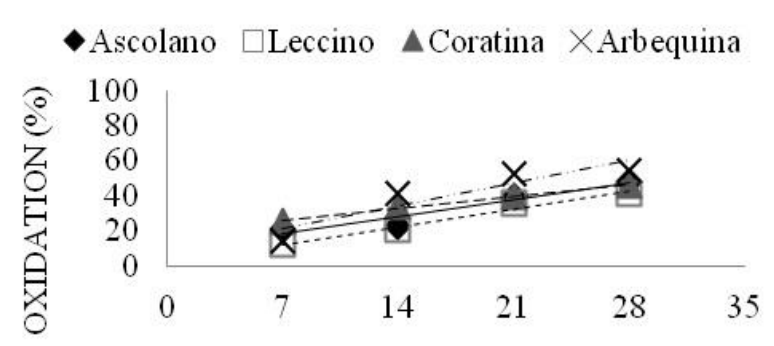

IN VITRO CULTIVATION DAYS

\section{SUMMER}

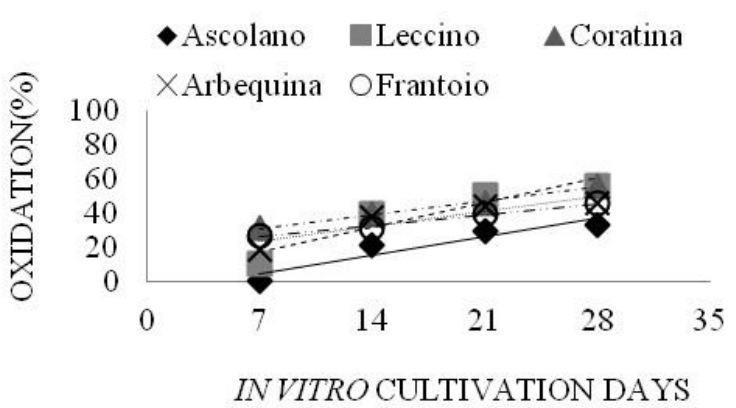

Ascolano $\mathrm{y}=9.80 \mathrm{x}+18.12 \mathrm{R}^{2}=0.93$

Leccino $y=10.20 x+12.30 \quad R^{2}=0.98$

Coratina $y=6.87 x+25.62 \quad R^{2}=0.99$

Arbequina $y=12.91 x+21.25 R^{2}=0.83$

\begin{abstract}
Ascolano $\mathrm{y}=9.80 \mathrm{x}+18.12 \mathrm{R}^{2}=0.93$
Leccino $\mathrm{y}=10.20 \mathrm{x}+12.30 \mathrm{R}^{2}=0.98$

Coratina $\mathrm{y}=6.87 \mathrm{x}+25.62 \quad \mathrm{R}^{2}=0.99$

Arbequina $\mathrm{y}=12.91 \mathrm{x}+21.25 \mathrm{R}^{2}=0.83$
\end{abstract}

Figure 2. Percentage of oxidized olive tree explants collected in the Fall (A), Winter (B), Spring (C) and Summer (D) and established in vitro, 2013. Pelotas, RS, Brazil. 2014.

\section{FALL}

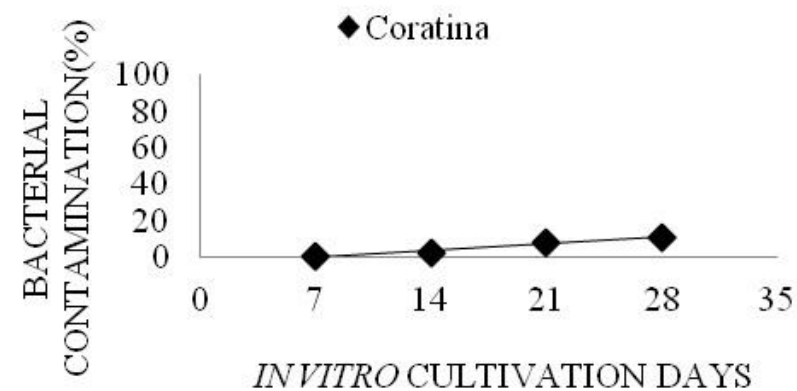

Coratina $\mathrm{y}=3.74 \mathrm{x}-0.42 \mathrm{R}^{2}=0.95$

A

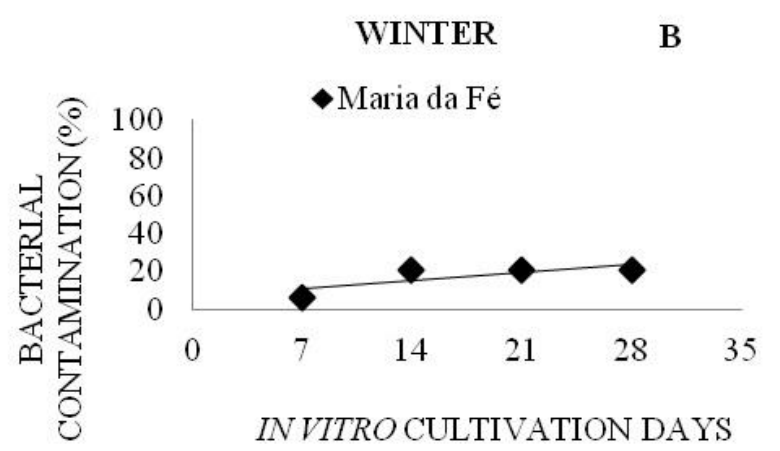

Maria da Fé $y=4.37 x+10.62 R^{2}=0.60$

Figure 3. Percentage of olive tree explants contaminated by bacteria, collected in the Fall (A) and Winter (B) and established in vitro, 2012. Pelotas, RS, Brazil. 2014. 
As for the olive tree explants oxidation, survival and establishment percentages, there was no interaction between the tested cultivars and collection periods. The highest oxidation percentages were shown by cultivars Frantoio in the Fall and Arbequina in the Winter, differing significantly from the collection realized in the Summer (Table 3). Costa et al. (2007) observed a strong difference in regards to different periods of the year for the establishment of Lippia sidoides Cham, considering that the dry period, when the relative air humidity was lower, favored the establishment; however, during the rainy season, there was greater incidence of microorganisms, mainly endogenous bacteria, plus oxidation.

Table 3. Percentage of oxidized olive tree explants established and survivors, collected in different seasons of the year, at 45 days of in vitro cultivation, 2012. Pelotas, RS, Brazil. 2014.

\begin{tabular}{ccccc}
\hline & \multicolumn{4}{c}{ Oxidation $(\%)$} \\
\cline { 2 - 5 } & Fall & Winter & Spring & Summer \\
\hline Ascolano 315 & $25.00 \mathrm{~b}^{1}$ & $75.00 \mathrm{a}$ & $70.83 \mathrm{a}$ & $58,33 \mathrm{a}$ \\
Leccino & $39.58 \mathrm{~b}$ & $75.00 \mathrm{a}$ & $72.91 \mathrm{a}$ & $66.67 \mathrm{ab}$ \\
Maria da Fé & $29.16 \mathrm{ab}$ & $50.00 \mathrm{a}$ & $16.66 \mathrm{~b}$ & $50.00 \mathrm{a}$ \\
Coratina & $50.00 \mathrm{ab}$ & $29.16 \mathrm{~b}$ & $77.08 \mathrm{a}$ & $68.75 \mathrm{a}$ \\
Arbequina & $39.58 \mathrm{~b}$ & $83.33 \mathrm{a}$ & $54.16 \mathrm{~b}$ & $45.83 \mathrm{~b}$ \\
Frantoio & $83.33 \mathrm{a}$ & $64.58 \mathrm{ab}$ & $79.16 \mathrm{a}$ & $47.91 \mathrm{~b}$ \\
\hline & \multicolumn{2}{c}{ Established $(\%)$} & \\
\hline Ascolano 315 & $31.25 \mathrm{a}$ & $2.08 \mathrm{c}$ & $18.75 \mathrm{ab}$ & $4.16 \mathrm{bc}$ \\
Leccino & $27.08 \mathrm{a}$ & $4.16 \mathrm{~b}$ & $16.67 \mathrm{ab}$ & $8.33 \mathrm{~b}$ \\
Maria da Fé & $16.67 \mathrm{~b}$ & $0.00 \mathrm{c}$ & $62.50 \mathrm{a}$ & $4.16 \mathrm{bc}$ \\
Coratina & $14.58 \mathrm{a}$ & $6.25 \mathrm{a}$ & $12.50 \mathrm{a}$ & $14.58 \mathrm{a}$ \\
Arbequina & $37.50 \mathrm{a}$ & $0.00 \mathrm{~b}$ & $2.08 \mathrm{~b}$ & $14.42 \mathrm{~b}$ \\
Frantoio & $8.33 \mathrm{ab}$ & $12.5 \mathrm{ab}$ & $0.00 \mathrm{~b}$ & \\
\hline \multicolumn{2}{c}{ Survivors $(\%)$} & $10.41 \mathrm{a}$ \\
\hline Ascolano 315 & $0.00 \mathrm{~b}$ & $10.42 \mathrm{ab}$ & $10.42 \mathrm{ab}$ & $8.33 \mathrm{a}$ \\
Leccino & $6.25 \mathrm{a}$ & $10.42 \mathrm{a}$ & $10.42 \mathrm{a}$ & $6.24 \mathrm{ab}$ \\
Maria da Fé & $0.00 \mathrm{~b}$ & $0.00 \mathrm{~b}$ & $14.58 \mathrm{a}$ & $8.33 \mathrm{a}$ \\
Coratina & $12.50 \mathrm{a}$ & $12.50 \mathrm{a}$ & $10.41 \mathrm{a}$ & $6.16 \mathrm{a}$ \\
Arbequina & $4.16 \mathrm{a}$ & $0.00 \mathrm{a}$ & $2.08 \mathrm{a}$ \\
Frantoio & $4.16 \mathrm{a}$ & $8.33 \mathrm{a}$ & $14.58 \mathrm{a}$ &
\end{tabular}

${ }^{1}$ Lowercase letters differ among them in the line by the Tukey test at $5 \%$ of probability.

\section{CONCLUSIONS}

The WPM culture medium promotes higher percentage of olive tree explants establishment.

There is higher phenolic oxidation in olive tree explants collected in winter.

Spring is recommended for cultivar Maria da Fé explants collection, while cultivars

Ascolano 315 and Arbequina show higher in vitro establishment rate in the fall.

\section{ACKNOWLEDGEMENT}

To the Coordination for the Improvement of Higher Education Personnel (CAPES) for granting the scholarships.

\section{REFERENCES}

Bassan JS, Reiniger LRS, Rocha BHG, Severo CRP and Flôres AV (2006) Oxidação fenólica, tipo de explante e meios de cultura no estabelecimento in vitro de Canafístula (Peltophorum dubium (SPRENG.) TAUB.). Ciência Florestal 16(4): 381-390.

Brondani GL, Hansel FA, Dutra LF and Wendling I (2010) Desinfestação e meio de cultura para o estabelecimento in vitro de segmentos nodais de Liquidambar styraciflua. Floresta 40(3): 541-554. 
Campanhia nacional de abastecimento (2009). Indicadores da agropecuária. Brasília. http://www.conab.gov.br/conabweb/index.php?PAG=212. Acessado em 14 dez. 2013.

Costa AS, Arrigoni MFB, Blank AF, Mendonça AB, Amancio VF and Ledo AS (2007) Estabelecimento de alecrim-pimenta in vitro. Horticultura Brasileira 25: 68-72.

Coutinho EF, Jorge RO and Costa VB (2015) Propagação. Coutinho EF, Jorge RO, Haerter JA and Costa VB (eds). Oliveira: Aspectos técnicos e cultivo no Sul do Brasil. Embrapa, Brasília, pp.86-95.

Dias MM, Nietsche S and Pereira MCT (2013) Carvão ativado e estiolamento no estabelecimento in vitro de romãzeira. Tecnologia \& Ciência Agropecuária 7(1): 1-5.

Donini PL, Schuch MW, Ribeiro MDF, Souza JAD and Soares GC (2008a) Avaliação da resposta de três cultivares de oliveira ao cultivo in vitro sob diferentes comprimentos de onda luminosa e efeitos da combinação de Zeatina e ácido giberálico. Scientia Agraria 9(2): 229-233

Donini LP, Schuch MW, Ribeiro MF, Souza JA and Soares GC (2008b) Estabelecimento in vitro de oliveira cv. 'Arbequina' para início da micropropagação. Ciência Rural 38(6): 1769-1772.

Erig AC and Schuch MW (2003) Tipo de explante e controle da contaminação e oxidação no estabelecimento in vitro de plantas de macieira (Malus domestica BORKH.) cvs. Galaxy, Maxigala e Mastergala. Revista Brasileira de Agrociência 9(3): 221-227.

Jorge RO (2013) O Brasil quer ser o país do azeite. http://www.anba.com.br/noticia/19826142/especiais/brasilquer-ser-pais-do-azeite/. Acessado em: 24 fev. 2014.

Lloyd G and Mccown B (1980) Commercially-feasible micropropagation of mountain laurel, kalmia latifolia, by use os shoot-tip culture. Combined Proceedings International Plant Propagators Society 30: 421-427.

Machado AA and Conceição AR (2010) Sistema de análise estatística para Windows. WinStat. Versão 1.0. UFPel. Murashige T and Skoog F (1962) A revised medium for rapid growth and biossay with tabacco tissue cultures. Physiologia Plantarum 15: 473-497.

Oliveira AF, Vieira Neto J, Gonçalves ED and Mesquita HAD (2009) Pioneirismo marca pesquisa sobre oliveira em Minas Gerais. Informe Agropecuário 30: 109-117.

Palu EG, Corrêa LS, Suzuki AN and Boliani AC (2011) Uso de antibióticos para o controle de bactérias endógenas visando à micropropagação da figueira. Revista Brasileira de Fruticultura 33 (2): 587-592.

Pelizza TR, Silveira FN, Muniz J, Grimaldi F, Rufato L and Kretzschmar AA (2013) Estabelecimento in vitro de mirtileiro: cultivares Bluecrop, Duke e Misty. Plant Cell Micropropagation 9(1-2): 24-29.

Rugini E (1984) In vitro propagation of some olive (Olea europaea sativa L.) cultivars with different root-ability, and medium development using analytical data from developing shoots and embryos. Scientia Horticulturae 24(2): 123-134.

Scherer-Salvaro LM, Echer MDM, Guimarães FV, Dall'oglio-chaves IE and Fortes AMT (2009) Épocas de coleta de explantes e fitoreguladores na multiplicação in vitro de citronela de java. Scientia Agraria 10(4): 275-282.

Schuch MW and Peil RMN (2012) Soilless cultivation systems: A new approach in fruit plants propagation in southern Brazil. Acta Horticulturae 952: 877-883.

Taiz L and Zeiger E (2013) Fisiologia vegetal. 5.ed. Artmed, Porto Alegre, 918p.

Teramoto JRS, Bertoncini EI and Pantano AP (2013) Mercado dos produtos da oliveira e os desafios Brasileiros. Informações Econômicas 43(2): 24-32.

Received: June 13, 2017.

Accepted: October 17, 2017.

Published: February 12, 2018.

Agronomy Science and Biotechnology, Volume 4, Issue 1, Pages 01 - 07, 2018 